\title{
Multivariate climatic effects and declining avian populations in an alkaline grassland complex
}

\author{
Zsolt Végvári $^{1, *}{ }^{,}$Zoltán Barta ${ }^{2}$ \\ ${ }^{1}$ Department of Conservation Zoology, Hortobágy National Park Directorate, University of Debrecen, Sumen u. 2, \\ Debrecen 4024, Hungary \\ ${ }^{2}$ MTA-DE Lendület Behavioural Ecology Research Group, Department of Evolutionary Zoology, University of Debrecen, \\ Egyetem tér 1, Debrecen 4032, Hungary
}

\begin{abstract}
As shown by recent studies, the population dynamics of many avian species have been affected by global climatic processes. Nevertheless, the number of studies on the effects of multivariate climatic predictors is still rather low. Using a long-term dataset of 19 species breeding in the Hortobágy (Hungary), considered the largest unbroken alkaline steppe in Europe, we estimated the effects of global and local climatic variables on avian population trends. Our results indicate that the population dynamics of several species might be driven by multivariate climatic effects. Specifically, the population trends of long-distance migratory species increasing in the Hortobágy were affected by both the NAO inducing milder climatic conditions in the southern part of Europe and increasing trends in Sahel rainfall. In turn, short-distance migrants reacted to warming winters through population growth. Additionally, negative population trends correlated with climatic parameters in several species of key conservation importance, with unknown causes of decline. In sum, we suggest that a sound understanding of multivariate climatic effects on avian populations is needed to outline more effective management plans that help avoid the erroneous attribution of causes of failure and success in practical conservation.
\end{abstract}

KEY WORDS: Climatic change $\cdot \mathrm{NAO} \cdot$ Sahel rainfall index $\cdot$ Population dynamics $\cdot$ Alkaline steppe $\cdot$ Hortobágy

Resale or republication not permitted without written consent of the publisher

\section{INTRODUCTION}

Global climatic change has been demonstrated to affect not only phenological responses in various plant and animal taxa (Peñuelas \& Filella 2001, Walther et al. 2002, Parmesan \& Yohe 2003, MacMynowski \& Root 2007) but also population trends (Green et al. 2003, UNEP/CMS 2006), often leading to serious declines (Eglington \& Pearce-Higgins 2012, Moritz \& Agudo 2013). Specifically, several studies have suggested that the population dynamics of some species in the focus of nature conservation are driven by climatic change (Sæther et al. 2004, Both et al. 2006, Møller et al. 2008, Sandvik \& Erikstad 2008). Indeed, the results of recent studies have demonstrated that the advancement of spring arrival dates can be associated with population trends in several avian species (Sæther et al. 2004, Møller et al. 2008, Knudsen et al. 2011).

There is accumulating evidence that the population dynamics of avian species correlate with climatic parameters on a continental scale, in both breeding and wintering grounds (Szép 1995, Møller et al. 2008, Csörg et al. 2009). These studies suggest that various climatic factors can affect birds in different periods of their life cycles (Gordo 2007). Specifically, it has recently been suggested that winter mean values of the NAO explain much of the variation in population size in North Atlantic seabirds (Sandvik \& Erikstad 2008). Further, the population dynamics of a few spe- 
cies breeding in Europe are known to be influenced by the African climate, especially by precipitation anomalies of the Sahel zone during the rainy season (Szép 1995, Gordo et al. 2005, Gordo \& Sanz 2006, Saino et al. 2007). Up to now, some studies suggested that a northward shift of the wintering quarters of European breeding birds is related to changes in global climate, such as the NAO and Sahel climate (Wormworth \& Mallon 2001, UNEP/CMS 2006, Harris 2008). However, changes in migratory strategies, such as switching from migratory to resident in some populations, are attributed to a response to climatic change at the regional level (Harris 2008). Similarly, milder winters are known to facilitate population growth in resident species (Ecsedi 2004, BirdLife International 2006). Although a few studies have already documented the importance of a multivariate description of climatic effects in explaining the responses to climatic change in birds (MacMynowsky \& Root 2007), only a very limited set of studies have so far attempted to explore the effects of multivariate climatic variables on population trends of species of key conservation importance (Pol et al. 2010, Nilsson et al. 2011, Jenouvrier 2013).

In this study, we aim to explore how multivariate climatic factors can explain population trends of breeding bird species between 1948 and 2007 in the Hortobágy National Park (HNP). The HNP represents an ideal site to carry out this investigation, as the area is the largest compact alkaline steppe in Europe, harbouring a large number of threatened avian species, in some cases with outstandingly high population sizes (Ecsedi 2004). Although the majority of bird species of enhanced conservation value breeding in the Hortobágy has been exhibiting increasing population trends in the past 2 decades, a few character species of the alkaline grasslands, such as Kentish plover Charadrius alexandrinus, collared pratincole Glareola pratincola and short-toed lark Calandrella brachydactyla, have disappeared as breeding species from the HNP during the past 15 yr. Since previous studies have attributed this series of extinctions to habitat alteration owing to an overall decrease in grazing intensity (Ecsedi 2004), important features of medium-scale management plans were based on this assumption (Göry \& Kapocsi 2005, Ecsedi et al. 2006). However, the effects of climatic change have never been investigated in relation to species loss in alkaline steppes. Accordingly, we investigate the associations between population trends and climatic variables on a global and regional scale to facilitate the improved planning and evaluation of future species-specific management projects. To do so, we con- sider the following hypotheses to be tested. As global climatic processes such as the NOA and Sahel climate influence population changes of migratory birds, we expect that (1) positive winter mean values of the NAO induce population growth of migratory birds, as survival rates are predicted to increase in milder winters (Sandvik \& Erikstad 2008); (2) decreasing values of precipitation in the Sahel zone induce population decline of migrant avian populations (as wetland birds use temporary and permanent wetland habitats in both wintering and breeding grounds, and for non-wetland species, rainfall stimulates vegetation growth and thus invertebrate and fruit abundance in the Sahel zone [Schaub et al. 2005, Gordo \& Sanz 2006, Saino et al. 2007] — annual variation is a robust proxy for annual variation in food for both wetland and non-wetland birds [Newson et al. 2009, Pearce-Higgins \& Green 2014]); and (3) as local climate has been shown to affect breeding population sizes directly and indirectly (warmer springs induce greater breeding success and warmer winters facilitate earlier spring arrivals [Julliard et al. 2004]), we predict that increases in both winter and spring weather promote breeding success, survival rates and therefore population sizes.

\section{METHODS}

\subsection{Population data}

Data on population sizes of breeding species were collected in the HNP, located in eastern Hungary. Here, the effects of climatic change on plant phenology and bird migration have already been demonstrated (Walkovszky 1998, Kovács-Láng et al. 2002, Végvári et al. 2010). Wetland areas acknowledged by the Ramsar Convention cover 27000 ha in the HNP, owing to its importance in protecting breeding sites for waterbirds of key conservation importance (e.g. pygmy cormorant Phalacrocorax pygmaeus, spoonbill Platalea leucorodia and ferruginous duck Aythya nyroca). In total, 147 avian species breed in the HNP, including 3 globally threatened species (saker falcon Falco cherrug, great bustard Otis tarda and aquatic warbler Acrocephalus paludicola; Ecsedi 2004).

We collected breeding bird population data (number of breeding pairs - with the exception of the great bustard, for which the number of individuals was counted, and the aquatic warbler, for which only the number of singing males can be estimated); the sources were Ecsedi (2004) and the database of the HNP directory. Only those species which met the fol- 
lowing criteria were included in our database (following MacMynowski \& Root 2007): (1) no gap longer than 3 yr between years with known population size, (2) a time span of at least 10 yr with no gap longer than $3 \mathrm{yr}$, and (3) the total number of years without population data is less than one-third of the years within the continuous time span with data. In total, data on population sizes of only 19 of 147 (18 non-passerines, predominantly waterbirds, and 1 passerine) avian species breeding in the Hortobágy met these criteria.

\subsection{Climatic variables}

To calculate the association between population development and climatic variables on a continental scale, we used 2 global climatic parameters: (1) the NAO, which describes the fluctuations in the difference of atmospheric pressure at sea level between the Icelandic low and the Azores high, and is associated with the strength and direction of westerly winds and storm tracks across the North Atlantic; and (2) the Sahel rainfall index (SRI), a measurement of precipitation anomalies in the African Sahel region during the rainy season (Dai et al. 2004). We obtained NAO values and Sahel indexes using the database of the Joint Institute for the Study of the Atmosphere and Ocean (http://jisao.washington.edu/data/).

Climatic variables on the local scale were calculated as follows. As weather data measured at the nearest meteorological station in Debrecen, eastern Hungary $\left(47^{\circ} 30^{\prime} \mathrm{N}, 21^{\circ} 10^{\prime} \mathrm{E}\right), 30 \mathrm{~km}$ from the study, were not available prior to 1948 , mean monthly temperature data for Budapest were obtained from the climate database of NOAA (ftp://ftp.ncdc.noaa.gov/ pub/data/ghcn/v2/). To assess the consistency of climatic predictors measured in Budapest and Debrecen, Pearson's correlation coefficients were calculated between the mean monthly temperature data from these stations. As the pairwise correlations were strong and highly significant $(\mathrm{r}=0.705, \mathrm{n}=61, \mathrm{p}<$ 0.0001 for spring and $\mathrm{r}=0.837, \mathrm{n}=61, \mathrm{p}<0.0001$ for winter), we used only the continuous records available for the whole study period from Budapest.

To control for climatic patterns experienced during wintering prior to the breeding season, we included their winter (previous November to March of the given year) values, and to investigate the effects of climatic predictors during the breeding season, we included spring values (February to May of the given year) calculated as the means of local monthly mean temperatures.

\subsection{Statistical analyses}

To estimate temporal trends in climatic variables, we fitted linear regressions on each climatic predictor as a function of years. To evaluate population trends, we conducted linear regressions between population sizes as responses and years. Significantly positive slopes indicate a growing population size, and significantly negative values denote decreasing population trends, while non-significant population trends are considered stable populations. To control for temporal autocorrelations, for all species we used $\ln \left(N_{t} / N_{t-1}\right)$ as the response variable, which is a metric of the population growth rate, calculated as the simple ratio between the population size at year $t\left(N_{t}\right)$ and the population size the year before $\left(N_{t-1}\right)$, which we log transformed to improve its fit as a linear response. Accordingly, we employed the full model $\ln \left(N_{t} / N_{t-1}\right)=N_{t-1}+\mathrm{SRI}+$ winter $\mathrm{NAO}+$ winter mean $T+$ spring mean $T$ with the exception of the great bustard, considered a resident species, for which we included only local weather parameters; all other species in our database are predicted to be influenced by both global climatic parameters (Ecsedi 2004).

To assess associations between the response variable and climatic variables, we formulated multivariate models for each species including population size of the previous year and all possible combinations of the predictors (NAO, SRI, local spring and winter mean temperatures). The relative importance of the predictors was evaluated by information-theoretic model comparison (Burnham \& Anderson 2002), in which inference is based on the complete set of possible models. First, we calculated model-averaged parameter estimates $(\beta)$ as well as unconditional standard errors ( $\mathrm{SE}_{\mathrm{u}}$ i Burnham \& Anderson 2002) of each variable by the sums of their Akaike weights across all models. Akaike differences $\left(\triangle \mathrm{AIC}_{\mathrm{c} i}=\mathrm{AIC}_{\mathrm{c} i}\right.$ - $\mathrm{AIC}_{\mathrm{cmin}}$, where $\mathrm{AIC}_{\mathrm{c}}$ is Akaike's information criterion corrected for small sample size, $\mathrm{AIC}_{\mathrm{ci}}$ is the $\mathrm{AIC}_{\mathrm{C}}$ value for a given model, and $\mathrm{AIC}_{\mathrm{cmin}}$ is the lowest $\mathrm{AIC}_{\mathrm{C}}$ value) in the range 0 to 2 indicate substantial level of empirical support of a given model (Burnham \& Anderson 2002). Next, we obtained the values of $\mathrm{AIC}_{\mathrm{C}}$ and the corresponding Akaike weight of each model $(\omega)$. Additonally, we calculated the significance of predictors using Z-statistics, provided by the functionality of the MuMIn package.

To investigate the role of climatic variables in influencing population trends, we ordered the models of climatic predictors by their sum of Akaike weights $(\Sigma)$ within each species and assigned a rank 
in increasing order to them, thus assigning the lowest ranks to the best-supported predictors. These ranks are of importance, as these metrics are expected to show if the different groups of species, as grouped either by population trend or migratory behaviour, present similarities as to which-if any-of the climatic parameters are influencing them the most. To calculate these ranks, for a given climatic variable, we extracted the ranks of models containing the given climatic variable and averaged their ranks for increasing, stable and decreasing population trend groups. Similarly, we assessed the effect of migration strategy on the population response to climate by averaging the ranks of Akaike $\Sigma$ s of climatic proxies across long- and shortdistance migrants. As we had only 2 resident species in the dataset, we omitted this category from this analysis. For all analyses, we used the R statistical computing environment (R Development Core Team 2014), including its lme4 (Bates \& Maechler 2009) and MuMIn (Barton 2011) packages.

\section{RESULTS}

\subsection{Trends in climate variables}

We detected no temporal trends in any of the weather metrics used in the models ( $p>0.07$ for all cases).

\subsection{Population trends}

Of 19 species, 12 showed significantly changing population trends over the study period (Table 1). With the exception of 2 waders (collared pratincole and Kentish plover, Fig. 1) and the great bustard, significant associations indicated positive population trends over the study period. Increasing population trends were exhibited by 3 species belonging to the order Ciconiiformes as well as saker falcon, great bustard, 3 waders (all marsh terns) and a single passerine (Table 1).

\subsection{Effects of climatic parameters}

Considering models of substantial support $\left(\triangle \mathrm{AIC}_{\mathrm{C}}\right.$ $<2.0$ ), population size of the previous year was included in all species except black-headed gull and white-winged tern. Supported models included either the NAO or SRI for 13 migrant birds. Both global climatic parameters were present in supported models of spoonbill, squacco heron, little egret, night heron and white-winged tern. Weather parameters describing local climate were present in models fitted for all species except black-headed gull (Table 2, Table S1 in the Supplement at www.int-res.com/ articles/suppl/c068p039_supp.pdf).

Model averaging showed that model-averaged parameter estimates of the NAO or SRI were signifi-

Table 1. Results of linear regression models between population sizes of avian species breeding in the Hortobágy and years. Bold: significant associations

\begin{tabular}{|c|c|c|c|c|c|c|c|}
\hline Scientific name & Common name & Migration type & $F_{1, \mathrm{df} 2}$ & df2 & $\mathrm{r}^{2}$ & Slope & $\mathrm{p}$ \\
\hline Nycticorax nycticorax & Night heron & Long-distance & 4.260 & 23 & 0.156 & 0.288 & 0.050 \\
\hline Ardeola ralliodes & Squacco heron & Long-distance & 4.174 & 26 & 0.138 & 0.109 & 0.051 \\
\hline Egretta garzetta & Little egret & Long-distance & 3.611 & 26 & 0.122 & 0.100 & 0.069 \\
\hline Egretta alba & Great white egret & Short-distance & 174.760 & 26 & 0.870 & 1.380 & 0.001 \\
\hline Ciconia ciconia & White stork & Long-distance & 7.131 & 15 & 0.322 & 0.053 & 0.017 \\
\hline Plegadis falcinellus & Glossy ibis & Long-distance & 2.358 & 26 & 0.083 & 0.052 & 0.137 \\
\hline Platalea leucorodia & Eurasian spoonbill & Long-distance & 176.439 & 58 & 0.753 & 0.264 & 0.002 \\
\hline Falco cherrug & Saker falcon & Short-distance & 6.197 & 17 & 0.267 & 0.121 & 0.023 \\
\hline Otis tarda & Great bustard & Resident & 24.005 & 18 & 0.571 & -0.127 & 0.001 \\
\hline Himantopus himantopus & Black-winged stilt & Short-distance & 28.050 & 35 & 0.445 & 0.103 & 0.001 \\
\hline Recurvirostra avosetta & Avocet & Short-distance & 6.850 & 39 & 0.149 & 0.094 & 0.013 \\
\hline Burhinus oedicnemus & Stone curlew & Short-distance & 10.662 & 43 & 0.199 & 0.038 & 0.002 \\
\hline Glareola pratincola & Collared pratincole & Long-distance & 57.921 & 30 & 0.659 & -0.256 & 0.001 \\
\hline Charadrius alexandrinus & Kentish plover & Short-distance & 82.697 & 47 & 0.638 & -0.097 & 0.001 \\
\hline Larus ridibundus & Black-headed gull & Short-distance & 10.509 & 43 & 0.196 & 0.329 & 0.002 \\
\hline Chlidonias hybridus & Whiskered tern & Long-distance & 2.068 & 43 & 0.046 & 0.176 & 0.158 \\
\hline Chlidonias niger & Black tern & Long-distance & 0.003 & 43 & 0.001 & -0.004 & 0.956 \\
\hline Chlidonias leucopterus & White-winged black tern & Long-distance & 1.488 & 31 & 0.046 & 0.329 & 0.232 \\
\hline Acrocephalus paludicola & Aquatic warbler & Long-distance & 62.782 & 35 & 0.642 & 0.586 & 0.001 \\
\hline
\end{tabular}



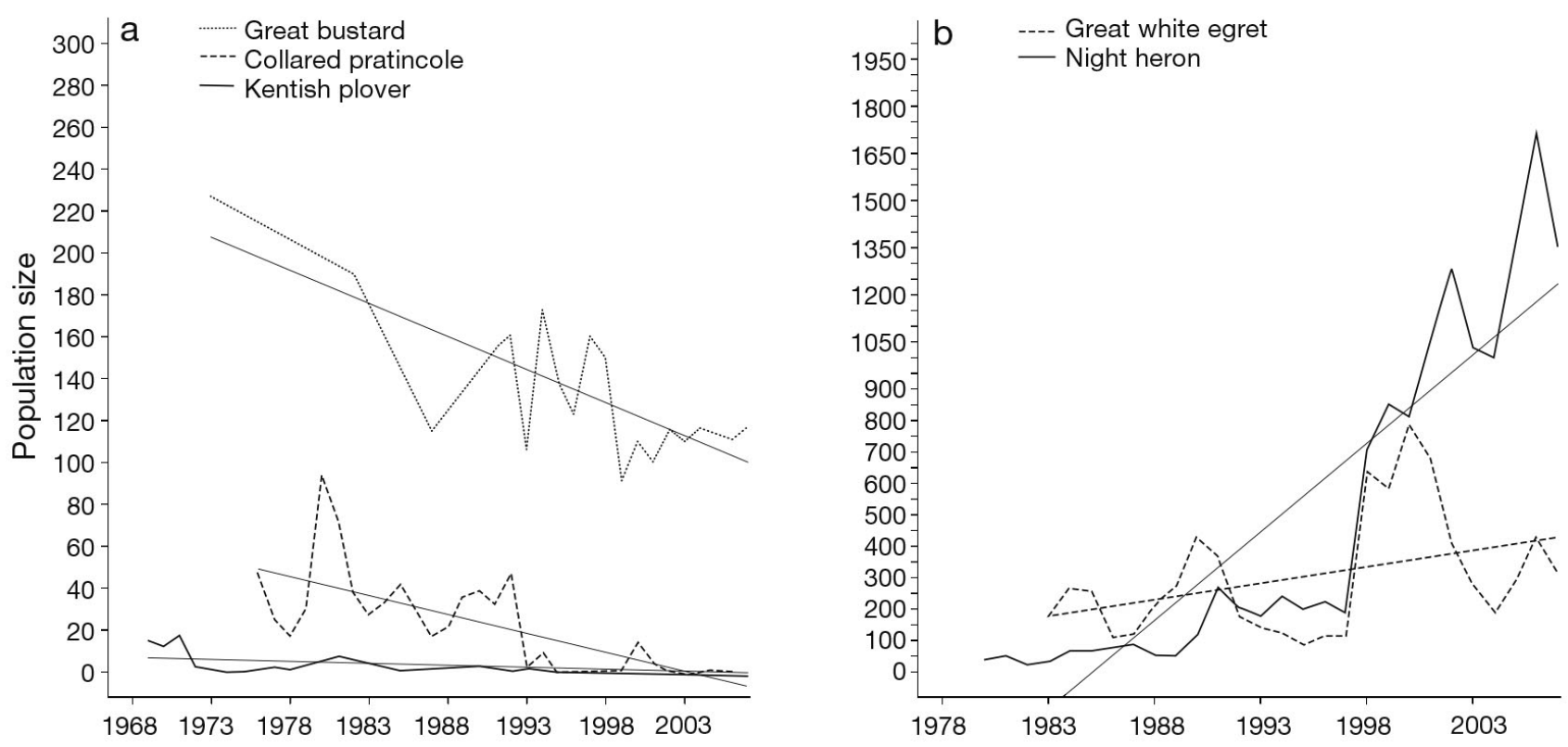

Fig. 1. Illustrative examples of population trends in the Hortobágy for (a) the decreasing populations of the Kentish plover, collared pratincole and great bustard as well as for (b) the increasing populations of the great white egret and night heron

cant in a single case: population changes of the squacco heron were negatively related to the winter NAO $(\beta=-0.3461, \mathrm{SE}=0.1583$; Table 2$)$. Modelaveraged parameter estimates of local weather parameters were significant only in 1 case: the population change of squacco heron was negatively related to spring mean temperatures $(\beta=0.5864, \mathrm{SE}=0.1583$; Table 2).

The results of ranking and averaging the relative importance of climatic predictors over population trend groups showed that for species with increasing population size, the SRI tended to be the most influential predictor, while the winter NAO was influential for decreasing population trends (Fig. 2). By contrast, the comparison of the importance of climatic predictors between long- and short-distance migrants showed that the SRI received the highest score for long-distance migrants, and winter mean temperature tended to be important for short-distance migrants (Fig. 3).

\section{DISCUSSION}

We demonstrated that (1) the most influential driver of annual population changes was the population size of the previous year, and (2) the NAO and SRI were also included in supported models fitted for population sizes of the majority of the bird species in our study. Furthermore, the winter NAO and spring mean temperatures emerged as significant climatic variables. These results might contribute to clarifying the reasons for dramatic population changes in bird species of key conservation importance. Further, we detected that the population dynamics of several species might be driven by multiple climatic effects, as suggested by previous investigations (Gordo 2007, Knudsen et al. 2011).

We showed that supported models fitted for the majority of the studied species with significantly increasing populations included either the SRI or NAO, which parallels the findings of several recent studies (Both et al. 2006, Møller et al. 2008, Sandvik \& Erikstad 2008). Our result that the SRI and NAO can be considered influential factors behind the response to climatic changes in declining species and had low importance for species with increasing populations is in line with the findings of a recent study which detected that one of the most influential predictors of population dynamics was the NAO in the whitethroated dipper Cinclus cinclus (Nilsson et al. 2011). However, the importance of the NAO in governing population sizes may vary considerably among species: Sandvik \& Erikstad (2008) found no significant effect of the NAO in seabird populations. To account for this pattern, we propose 2 mutually non-exclusive explanations: (1) the number of species in our study is not high enough to control for phylogenetic dependence, which might mask patterns related to climatic sensitivity across species; and (2) the species in our 
Table 2. Model-averaged non-intercept parameter estimates, standard errors and confidence intervals of climatic proxies as well as ranks of absolute values of parameter estimates of climatic parameters for each species calculated across supported models $\left(\Delta_{i}<2.0\right)$. Bold values: predictors with significant $z$-values. $T$ : temperature; SRI: Sahel rainfall index

\begin{tabular}{|c|c|c|c|c|c|c|c|c|c|c|c|}
\hline Predictor & Rank & Estimate & $\mathrm{SE}$ & $z$ & $\mathrm{p}$ & Predictor & Rank & Estimate & $\mathrm{SE}$ & $z$ & $\mathrm{p}$ \\
\hline \multicolumn{6}{|c|}{ Nycticorax nycticorax } & Winter NAO & 4 & -0.0117 & 0.1893 & 0.0598 & 0.9523 \\
\hline Spring mean $T$ & 1 & 0.0315 & 0.0897 & 0.3412 & 0.733 & Spring mean $T$ & 3 & -0.0438 & 0.4096 & 0.1037 & 0.9174 \\
\hline Winter mean $T$ & 3 & 0.0107 & 0.0486 & 0.2107 & 0.8331 & \multicolumn{6}{|c|}{ Recurvirostra avosetta } \\
\hline Population & & -0.0006 & 0.0007 & 0.8768 & 0.3806 & Spring mean $T$ & 1 & 0.0736 & 0.4128 & 0.172 & 0.8634 \\
\hline SRI & 4 & -0.0055 & 0.044 & 0.1191 & 0.9052 & Winter NAO & 3 & 0.0634 & 0.2366 & 0.2595 & 0.7952 \\
\hline Winter NAO & 2 & -0.0159 & 0.0449 & 0.3444 & 0.7305 & Population & & 0.0077 & 0.0201 & 0.3753 & 0.7074 \\
\hline \multicolumn{6}{|c|}{ Ardeola ralloides } & Winter mean $T$ & 4 & -0.038 & 0.3602 & 0.1017 & 0.919 \\
\hline Spring mean $T$ & 1 & 0.5864 & 0.1583 & 3.5378 & 0.0004 & SRI & 2 & -0.0636 & 0.3507 & 0.1749 & 0.8611 \\
\hline SRI & 4 & -0.0006 & 0.0454 & 0.0128 & 0.9898 & \multicolumn{6}{|c|}{ Burhinus oedicnemus } \\
\hline Winter mean $T$ & 3 & -0.0101 & 0.0582 & 0.1656 & 0.8685 & Winter NAO & 2 & 0.0427 & 0.0484 & 0.8684 & 0.3852 \\
\hline Population & & -0.0216 & 0.0045 & 4.5614 & $<0.0001$ & SRI & 4 & 0.0029 & 0.03 & 0.0948 & 0.9245 \\
\hline Winter NAO & 2 & -0.3461 & 0.096 & 3.4408 & 0.0006 & Spring mean $T$ & 3 & -0.0107 & 0.0589 & 0.1784 & 0.8584 \\
\hline Egretta garzetta & & & & & & Population & & -0.0162 & 0.0153 & 1.0448 & 0.2961 \\
\hline SRI & 2 & 0.0446 & 0.0871 & 0.4988 & 0.6179 & Winter mean $T$ & 1 & -0.159 & 0.0871 & 1.7939 & 0.0728 \\
\hline Winter NAO & 3 & 0.0302 & 0.0626 & 0.472 & 0.637 & \multicolumn{6}{|c|}{ Glareola pratincola } \\
\hline Spring mean $T$ & 4 & 0.0175 & 0.1003 & 0.1702 & 0.8648 & Winter mean $T$ & 2 & 0.2487 & 0.477 & 0.5099 & 0.6101 \\
\hline Population & & -0.0035 & 0.004 & 0.8609 & 0.3893 & Population & & 0.1122 & 0.0308 & 3.5079 & 0.0005 \\
\hline Winter mean $T$ & 1 & -0.099 & 0.1224 & 0.7924 & 0.4281 & Winter NAO & 4 & 0.0254 & 0.1646 & 0.1481 & 0.8822 \\
\hline Egretta alba & & & & & & Spring mean $T$ & 3 & -0.0361 & 0.4169 & 0.0841 & 0.933 \\
\hline Winter mean $T$ & 2 & 0.0209 & 0.0519 & 0.3892 & 0.6971 & SRI & 1 & -0.8152 & 0.7571 & 1.0557 & 0.2911 \\
\hline Spring mean $T$ & 3 & 0.0108 & 0.0525 & 0.197 & 0.8438 & \multicolumn{6}{|c|}{ Charadrius alexandrinus } \\
\hline Population & & 0 & 0.0001 & 0.3036 & 0.7614 & Population & & 0.5033 & 0.1253 & 3.8269 & 0.0001 \\
\hline Winter NAO & 4 & -0.0035 & 0.0253 & 0.1335 & 0.8938 & Winter NAO & 2 & 0.1273 & 0.2756 & 0.4488 & 0.6536 \\
\hline SRI & 1 & -0.026 & 0.0585 & 0.431 & 0.6665 & Winter mean $T$ & 4 & 0.0432 & 0.302 & 0.1371 & 0.891 \\
\hline Ciconia ciconia & & & & & & Spring mean $T$ & 3 & -0.1256 & 0.4442 & 0.273 & 0.7849 \\
\hline SRI & 1 & 0.0493 & 0.045 & 1.0461 & 0.2955 & SRI & 1 & -0.814 & 0.7354 & 1.0813 & 0.2796 \\
\hline Spring mean $T$ & 2 & 0.0101 & 0.0287 & 0.3333 & 0.7389 & \multicolumn{6}{|c|}{ Larus ridibundus } \\
\hline Winter mean $T$ & 3 & 0.0022 & 0.0147 & 0.1354 & 0.8923 & Winter NAO & 1 & 0.0924 & 0.3646 & 0.2278 & 0.8198 \\
\hline Winter NAO & 4 & -0.0013 & 0.0086 & 0.1403 & 0.8884 & SRI & 2 & 0.041 & 0.3452 & 0.1018 & 0.9189 \\
\hline Population & & -0.004 & 0.0014 & 2.6496 & 0.0081 & Spring mean $T$ & & 0.0114 & 0.2202 & 0.042 & 0.9665 \\
\hline Plegadis falcinel & ellus & & & & & Population & 4 & -0.0006 & 0.0016 & 0.3163 & 0.7517 \\
\hline SRI & 1 & 0.8785 & 0.9699 & 0.8829 & 0.3773 & Winter mean $T$ & 3 & -0.0267 & 0.2268 & 0.0985 & 0.9215 \\
\hline Winter mean $T$ & 2 & 0.2902 & 0.6442 & 0.4356 & 0.6631 & \multicolumn{6}{|c|}{ Chlidonias hybridus } \\
\hline Spring mean $T$ & 3 & 0.2699 & 0.7162 & 0.3653 & 0.7149 & Spring mean $T$ & 1 & 0.1099 & 0.3852 & 0.2742 & 0.7839 \\
\hline Population & & 0.0116 & 0.0694 & 0.1588 & 0.8738 & Winter mean $T$ & 4 & 0.0131 & 0.2766 & 0.0451 & 0.964 \\
\hline Winter NAO & 4 & -0.1509 & 0.4075 & 0.3576 & 0.7207 & Population & & -0.0005 & 0.0009 & 0.5047 & 0.6138 \\
\hline Platalea leucoro & odia & & & & & SRI & 3 & -0.0314 & 0.271 & 0.1098 & 0.9126 \\
\hline Spring mean $T$ & 1 & 0.0877 & 0.0779 & 1.1113 & 0.2664 & Winter NAO & 2 & -0.0378 & 0.1777 & 0.203 & 0.8391 \\
\hline Winter NAO & 3 & 0.0085 & 0.0199 & 0.4159 & 0.6775 & \multicolumn{6}{|c|}{ Chlidonias niger } \\
\hline Population & & -0.0005 & 0.0005 & 1.1241 & 0.261 & Winter NAO & 2 & 0.2144 & 0.3975 & 0.5244 & 0.600 \\
\hline SRI & 4 & -0.0063 & 0.0258 & 0.239 & 0.8111 & Spring mean $T$ & 4 & 0.073 & 0.4201 & 0.1651 & 0.8689 \\
\hline Winter mean $T$ & 2 & -0.0332 & 0.0585 & 0.5603 & 0.5753 & Winter mean $T$ & 3 & 0.0159 & 0.3477 & 0.0432 & 0.9656 \\
\hline Falco cherrug & & & & & & Population & & -0.0013 & 0.0045 & 0.291 & 0.7711 \\
\hline Spring mean $T$ & 3 & 0.0083 & 0.0557 & 0.1385 & 0.8899 & SRI & 1 & -0.2675 & 0.581 & 0.4459 & 0.6557 \\
\hline Winter NAO & 4 & 0.0032 & 0.031 & 0.0961 & 0.9234 & \multicolumn{6}{|c|}{ Chlidonias leucopterus } \\
\hline SRI & 2 & -0.0128 & 0.0607 & 0.1957 & 0.8449 & Population & & 0 & 0.0005 & 0.0383 & 0.9695 \\
\hline Population & & -0.0241 & 0.0251 & 0.9255 & 0.3547 & Winter NAO & 4 & -0.0116 & 0.2202 & 0.0508 & 0.9595 \\
\hline Winter mean $T$ & 1 & -0.0346 & 0.082 & 0.4021 & 0.6876 & Spring mean $T$ & 3 & -0.0629 & 0.5461 & 0.1117 & 0.9111 \\
\hline Otis tarda & & & & & & SRI & 2 & -0.3737 & 0.669 & 0.5466 & 0.5847 \\
\hline Winter mean $T$ & 1 & 0.0149 & 0.0311 & 0.4603 & 0.6453 & Winter mean $T$ & 1 & -0.5519 & 0.7682 & 0.7044 & 0.4812 \\
\hline Spring mean $T$ & 2 & -0.0024 & 0.0252 & 0.0912 & 0.9273 & \multicolumn{6}{|c|}{ Acrocephalus paludicola } \\
\hline Population & & -0.0045 & 0.0016 & 2.5899 & 0.0096 & Winter NAO & 1 & 0.0094 & 0.0326 & 0.2781 & 0.781 \\
\hline \multicolumn{6}{|c|}{ Himantopus himantopus } & Winter mean $T$ & 3 & 0.0045 & 0.0425 & 0.1014 & 0.9192 \\
\hline Population & & 0.2709 & 0.1123 & 2.3529 & 0.0186 & Population & & -0.0004 & 0.0005 & 0.7792 & 0.4359 \\
\hline SRI & 1 & 0.1697 & 0.4927 & 0.3366 & 0.7364 & SRI & 4 & -0.0029 & 0.0474 & 0.0581 & 0.9537 \\
\hline Winter mean $T$ & 2 & 0.1456 & 0.4282 & 0.3317 & 0.7401 & Spring mean $T$ & 2 & -0.0065 & 0.0498 & 0.1263 & 0.8995 \\
\hline
\end{tabular}




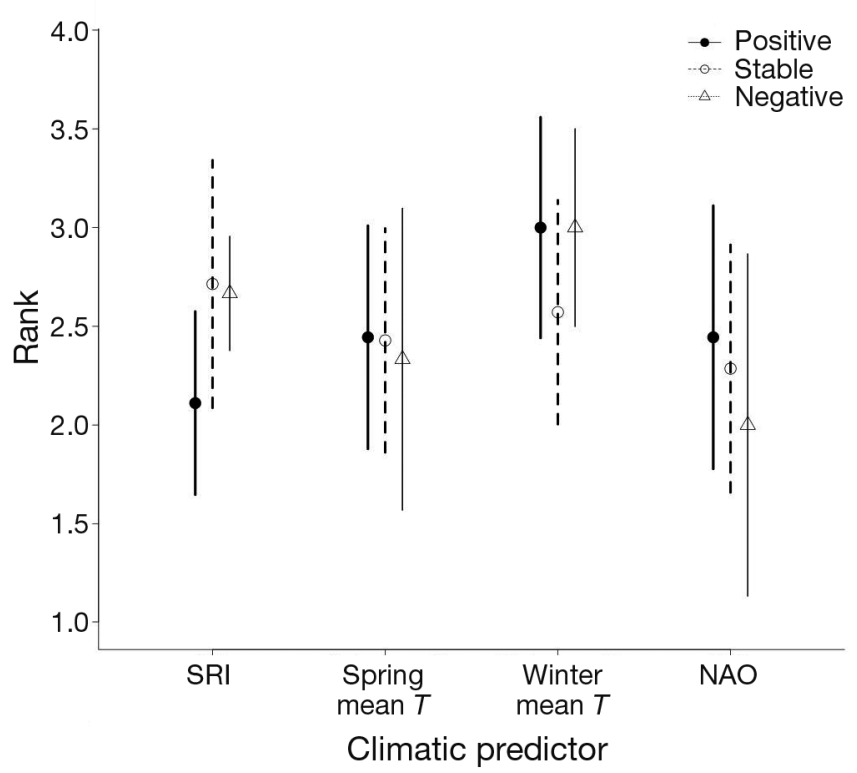

Fig. 2. Mean relative importance rank $( \pm \mathrm{SE})$ values of climatic predictors averaged for species with increasing, stable and decreasing populations. SRI: Sahel rainfall index; $T$ : temperature

study are different to those studied by Sandvik \& Erikstad (2008) and, hence, use different - continental - breeding habitats and migration routes, and are characterised by different life histories. Further, our analyses indicate that some species may be sensitive to both the NAO and SRI simultaneously, implying that species might be influenced by complex climatic mechanisms in different life-cycle periods, as suggested by Gordo (2007).

Our finding that the effects of Sahel climate and the NAO on population trends were stronger in longdistance migrants than in short-distance migrants might indicate more intensive carry-over effects of environmental conditions during migration and wintering for sub-Saharan migrants (Norris et al. 2004). However, the coupled effect of Sahel rainfall and North Atlantic weather (Bader \& Latif 2003) on the survival of migratory and wintering bird populations needs further research. Specifically, the populations of 4 of 5 species (spoonbill, squacco heron, little egret, night heron), supported by models which included both the SRI and NAO, were positively influenced by warmer and wetter winters, implying that bird populations which migrate or winter under weather conditions influenced by the NAO respond with population growth to, presumably, increased survival rates and food availability. Indeed, previous studies have demonstrated that changes in the French and Italian populations of the squacco heron and night heron were at least partially driven by

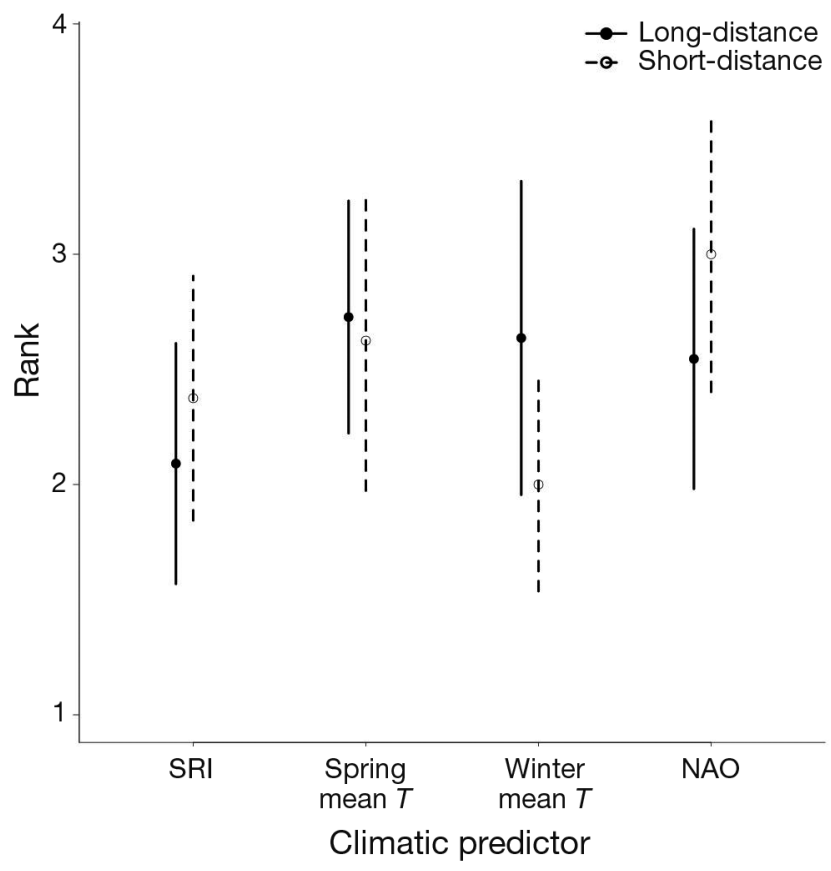

Fig. 3. Mean relative importance rank $( \pm \mathrm{SE})$ values of climatic predictors averaged for species with long- and shortdistance migration strategies. SRI: Sahel rainfall index; $T$ : temperature

trends in Sahel precipitation (Fasola et al. 2010), a mechanism which applies to other members of Ardeidae (Den Held 1981, Marion et al. 2006).

Similarly, the population sizes of short-distance migrants were more affected by local winter climate than those of long-distance migrants, which might imply the influence of coupling between local climate and the NAO (Luterbacher et al. 2004). Indeed, the majority of short-distance migrants in our study responded with significant population growth to winter warming. For example, such processes are observed in great bustards and great egrets, as shown by decreased mortality of first-year bustards and increased survival rates of adults of both species, indicated by the decreasing number of days with snow cover and increasing frequency of overwintering attempts of the great egret (Ecsedi 2004). Similarly, spoonbill exhibited significantly increasing population as a response to warming spring weather, which might be explained by the (1) prolongation of breeding as a result of earlier arrivals, which increases the success of replacement hatches; and (2) increase of nestling survival as a result of improved weather conditions (Végvári et al. 2006).

Our finding that several avian taxa in our study increased population size as a result of associations with African climate might suggest that sub-Saharan climatic trends have induced a change in migratory 
behaviour by shifting wintering grounds northwards, as proposed by recent investigations (Green et al. 2003, Harris 2008). This pattern parallels the results presented in previous studies stating that changing migratory behaviour by a northward shifting of the wintering grounds or becoming a partially resident species facilitates population growth (Maclean et al. 2007, Harris 2008). However, the climate-induced northward shift of wintering areas is limited by the Sahara, where habitat and food resources are lacking for most avian species. Although shifts of wintering grounds might thus be predicted towards the Middle East, no empirical evidence is available to support this hypothesis. Additionally, changes in food availability favouring earlier onset migration might modify survival rates, which thus affects population sizes (Both \& te Marvelde 2007). Further, our results indicating that population sizes of species breeding in the region are affected by African climate are in correspondence with the suggestions of previous studies (e.g. Szép 1995). Annual population sizes of both egrets increased with milder winter NAO values, promoting better survival changes in the northernmost part of the wintering areas.

Considering climatic predictors exhibiting significant $z$-values across all models, only the squacco heron showed relationships between population changes and climate. Therefore, other factors not related to climate are probably the main drivers of the population dynamics of the majority of the studied species, such as habitat structure or land use changes, for which unfortunately no historical records are available: (1) the primary drivers of population changes may include other ecological effects such as substantial changes in land use systems; and (2) the exact flyways and wintering areas of local populations are unknown, which calls for further studies involving satellite tracking of migratory species of conservation concern. The missing climatic effects of population changes in characteristic waders of alkaline wetlands are in line with studies demonstrating declines in many charadriid taxa, which are suggested to involve several anthropogenic effects such as substantial degrees of land use change and hunting pressure (Zockler et al. 2003). As population development of the saker falcon has been effectively aided by conservation actions such as the regular establishment of nest platforms, we propose that climatic responsiveness of population changes in this raptor might be masked by species-specific conservation management (Chavko 2010).

In our study, the aquatic warbler, a locally common wetland passerine of the study area, exhibited asso- ciations between climatic parameters and declining populations. This passerine is affected by the African climate in its wintering grounds and by the NOA during migration, as well as local climatic effects during breeding. It is classified as a habitat specialist preferring sedge marshes and is characterised by a highly complex mating system. Thus, disentangling climatic, habitat and social effects in driving population dynamics is rather challenging in the aquatic warbler, which consequently needs specific research involving individual tracking. As the reasons for population decrease in this species have been so far unknown in the region, our findings underline the importance of studying the effects of climate change on declining populations of endangered species. As the aquatic warbler is used as an indicator species for alkaline wetlands in the region, we suggest that caution should be applied in employing species with population trends related to climatic processes for assessing habitat management successes.

We reported that the NAO and SRI have influenced population dynamics in a smaller number of species than local winter and spring temperatures. This implies that climatic variables measured on the continental scale have less intense effects on population sizes than those on the regional scale. We demonstrated that population trends correlated with climatic parameters in several species of key conservation importance with previously unknown causes of decline. Hence, we suggest controlling for climatic effects when elaborating and evaluating management plans aimed at increasing the population size of endangered species. Specifically, we propose exploring population trends as a function of climate change before using them as designating species for protection areas. Employing such species to quantify habitat quality might be misleading in evaluating habitat improvements. This might be especially true in species that may respond to climatic processes at the global scale. To conclude, our results imply that a sound understanding of the multivariate effects of climatic change on avian populations is needed to outline more effective management plans that help avoid the erroneous attribution of causes of failure and success in practical conservation.

Acknowledgements. This work is supported by the TÁMOP 4.2.1./B-09/1/KONV-2010-0007 project. The project is implemented through the New Hungary Development Plan, co-financed by the European Social Fund and the European Regional Development Fund. During the study, Z.B. was supported by an OTKA grant (K75696). We are grateful to Miriam Hansbauer, Tibor Szép and Csaba Moskát for revising earlier versions of the manuscript. 


\section{LITERATURE CITED}

Barton J, Latif M (2003) The impact of decadal-scale Indian Ocean sea surface temperature anomalies on Sahelian rainfall and the North Atlantic Oscillation, Geophys Res Lett 30, 2169, doi:10.1029/2003GL018426

Barton K (2011) MuMIn: multi-model inference. R package version 1.0.0. https://cran.r-project.org/web/packages/ MuMIn/MuMIn.pdf

Bates D, Maechler M (2009) lme4: linear mixed-effects models using S4 classes. R package version 0.999375-31. http://CRAN.R-project.org/package=lme4 (accessed on 01 Jan 2010)

BirdLife International (2006) International action plan for the saker falcon (Falco cherrug). BirdLife International, Strasbourg

Both C, te Marvelde L (2007) Climate change and timing of avian breeding and migration throughout Europe. Clim Res 35:93-105

Both C, Bouwhuis S, Lessells CM, Visser ME (2006) Climate change and population declines in a long-distance migratory bird. Nature 441:81-83

Burnham KP, Anderson DR (2002) Model selection and multimodel inference: a practical information-theoretic approach, 2nd edn. Springer-Verlag, New York, NY

Chavko J (2010) Trend and conservation of saker falcon (Falco cherrug) population in western Slovakia between 1976 and 2010. Slovak Raptor J 4:1-22

Csörgö T, Karcza ZS, Halmos G, Magyar G and others (eds) (2009) Hungarian bird migration atlas. Kossuth Kiadó, Budapest (in Hungarian)

Dai A, Lamb PJ, Trenberth KE, Hulme M, Jones PD, Xie PP (2004) The recent Sahel drought is real. Int J Climatol 24: 1323-1331

Den Held, JJ (1981) Population changes in the purple heron in relation to drought in the wintering area. Ardea 69: 185-191

Ecsedi Z (ed) (2004) A Hortobágy madárvilága. Hortobágy Természetvédelmi Egyesület. Winter Fair, Balmazújváros-Szeged

Ecsedi Z, Oláh J Jr, Szegedi R (2006) Habitat management of Hortobágy ecoregion for bird protection. LIFE-Nature project of the Hortobágy Environmental Association in the Hortobágy, 2002-2006. www.hortobagyte.hu/life_ index.php (accessed on 11 Mar 2010)

Eglington SM, Pearce-Higgins JW (2012) Disentangling the relative importance of changes in climate and land-use intensity in driving recent bird population trends. PLoS ONE 7:e30407

Fasola M, Rubolini D, Merli E, Boncompagni E, Bressan U (2010) Long-term trends of heron and egret populations in Italy, and the effects of climate, human-induced mortality, and habitat on population dynamics. Popul Ecol 52:59-72

> Gordo O (2007) Why are bird migration dates shifting? A review of weather and climate effects on avian migratory phenology. Clim Res 35:37-58

Gordo O, Sanz J (2006) Climate change and bird phenology: a long-term study in the Iberian Peninsula. Glob Chang Biol 12:1993-2004

Gordo O, Brotons L, Ferrer X, Comas P (2005) Do changes in climate patterns in wintering areas affect the timing of the spring arrival of trans-Saharan migrant birds? Glob Chang Biol 11:12-21

Göry S, Kapocsi I (2005) Restoration of pannonic steppes and marshes. LIFE-Nature project in the Hortobágy National, Park 2002-2005. http://life2002.hnp.hu/en/html/hnpframe. html (accessed 11 Mar 2010)

Green RE, Harley M, Miles R, Scharlemann J, Watkinson A, Watts O (eds) (2003) CBP/United Nations Environment Programme-World Conservation Monitoring Centre (UNEP-WCMC), University of East Anglia, Norwich

Harris J (2008) Cranes respond to climate change. The ICF Bugle 34:2-14

Jenouvrier S (2013) Impacts of climate change on avian populations. Glob Chang Biol 19:2036-2057

Julliard R, Jiguet F, Couvet D (2004) Evidence for the impact of global warming on the long-term population dynamics of common birds. Proc R Soc B 271:S490-S492

Knudsen E, Lindén A, Both C, Jonzén N, Pulido F, Saino N, Stenseth NC (2011) Challenging claims in the study of migratory birds and climate change. Biol Rev Camb Philos Soc 86:928-946

Kovács-Láng E, Kröel-Dulay G, Lhotsky B, Garadnai J (2002) Indirect and direct approaches in studying the ecological effects of climate change in dry grasslands in Hungary. Grassland Sci Eur 7:700-701

> Luterbacher J, Dietrich D, Xoplaki E, Grosjean M, Wanner $\mathrm{H}$ (2004) European seasonal and annual temperature variability, trends, and extremes since 1500. Science 303: 1499-1503

Maclean IMD, Rehfisch MM, Delany S, Robinson RA (2007) The effects of climate change on migratory waterbirds within the African-Eurasian flyway. BTO Report No. 486. British Trust for Ornithology, Thetford

MacMynowski DP, Root TL (2007) Climate and the complexity of migratory phenology: sexes, migratory distance and arrival distributions. Int J Biometeorol 51:361-373

Marion L, Barbier L, Morin C (2006) Statut du blongios nain Ixobrychus minutus en France entre 1968 et 2004 et causes probables de l'evolution de ses effectifs. Alauda 74:155-170

> Møller AP, Rubolini D, Lehikoinen E (2008) Populations of migratory bird species that did not show a phenological response to climate change are declining. Proc Natl Acad Sci USA 105:16195-16200

Moritz C, Agudo R (2013) The future of species under climate change: resilience or decline? Science 341:504-508

Newson SE, Mendes S, Crick HQP, Dulvy NK and others (2009) Indicators of the impact of climate change on migratory species. Endang Species Res 7:101-113

Nilsson AL, Knudsen E, Jerstad K, Røstad OW, Walseng B, Slagsvold T, Stenseth NC (2011) Climate effects on population fluctuations of the white throated dipper Cinclus cinclus. J Anim Ecol 80:235-243

Norris DR, Marra PP, Kyser TK, Sherry TW, Ratcliffe LM (2004) Tropical winter habitat limits reproductive success on the temperate breeding grounds in a migratory bird. Proc R Soc B 271:59-64

Parmesan C, Yohe G (2003) A globally coherent fingerprint of climate change impacts across natural systems. Nature 421:37-42

Pearce-Higgins JW, Green RE (2014) Birds and climate change: impacts and conservation responses. Cambridge University Press, Cambridge

Peñuelas J, Filella I (2001) Responses to a warming world. Science 294:793-795

R Development Core Team (2014) The R project for statistical computing. R Foundation for Statistical Computing, Vienna. www.r-project.org/ (accessed on 01 July 2013) 
Sæther BE, Sutherland WJ, Engen S (2004) Climate influences on population dynamics. Adv Ecol Res 35:185-209

Saino N, Rubolini D, Jonzén N, Ergon T, Montemaggiori A, Stenseth NC, Spina F (2007) Temperature and rainfall anomalies in Africa predict timing of spring migration in trans-Saharan migratory birds. Clim Res 35:123-134

Sandvik H, Erikstad KE (2008) Seabird life histories and climatic fluctuations: a phylogenetic-comparative time series analysis of North Atlantic seabirds. Ecography 31: 73-83

Schaub M, Kania W, Köppen U (2005) Variation of primary production during winter induces synchrony in survival rates in migratory white storks Ciconia ciconia. J Anim Ecol 74:656-666

Szép T (1995) Relationship between west African rainfall and the survival of central European sand martins Riparia riparia. Ibis 137:162-168

UNEP/CMS (2006) Migratory species and climate change: impacts of a changing environment on wild animals. United Nations Environment Programme (UNEP)/Secretariat of the Convention on the Conservation of Migratory Species of Wild Animals (CMS), Bonn

Editorial responsibility: Nils Chr. Stenseth, Oslo, Norway van de Pol M, Vindenes Y, Sæther BE, Engen S, Ens BJ, Oosterbeek K, Tinbergen JM (2010) Effects of climate change and variability on population dynamics in a longlived shorebird. Ecology 91:1192-1204

Végvári Z, Fenyvesi L, Kapocsi I, Kovács G and others (2006) Population dynamics of the spoonbill in Hungary and its colony site selection in the Hortobágy National Park. EUROSITE Spoonbill Netw Newsl 4:45

> Végvári Z, Bókony V, Barta Z, Kovács G (2010) Life history predicts advancement of avian spring migration in response to climate change. Glob Chang Biol 16:1-11

Walkovszky A (1998) Changes in phenology of the locust tree (Robinia pseudoacacia L.) in Hungary. Int J Biometeorol 41:155-160

Walther GR, Post E, Convey P, Menzel A and others (2002) Ecological response to recent climate change. Nature 416:389-395

Wormworth J, Mallon K (2001) Bird species and climate change: the global status report. Climate Risk, Fairfield

Zockler C, Delany S, Hagemeijer W (2003) Wader populations are declining: How will we elucidate the reasons? Wader Study Group Bull 100:202-211

Submitted: February 12, 2015; Accepted: January 4, 2016 Proofs received from author(s): March 22, 2016 